\title{
Elemento Atrapalhador e Outros Princípios: a performatividade na poética dramático-realista
}

\author{
Rejane Kasting Arruda \\ Universidade Vila Velha \\ Email: rejane7karruda@yahoo.com.br
}

Resumo

Interroga-se a construção da atuação realista, especialmente no que diz respeito à poética do corpo, trabalhando a hipótese de que o ponto de partida deve estar na aleatoriedade da forma e do jogo para que o encontro com o enquadramento diegético se dê ao acaso. Para sustentar esta hipótese, descreve-se práticas de pesquisas laboratoriais, evidenciando as operações de extração e condensação de um significante para a construção do enquadramento diegético. São utilizadas proposições de Anne Bogart e Jacques Leqcoq, bem como a interface com outras áreas do conhecimento, como a Psicanálise de Jacques Lacan. Chega-se à conclusão da necessidade de um material que funcione como desestabilizador do arranjo, permitindo ao ator ser atravessado por uma experiência real cujas reações serão situadas, pelo olhar do espectador, no contexto diegético.

Palavras-chave

Poética do Corpo. Pedagogia do Teatro. Teatro Dramático.
Abstract

We interrogate The construction of realistic action, especially with regard to the poetics of the body,working the hypothesis that the starting point must be in the randomness of the form and game, so that the meeting with the diegetic framework can happen at random.To support this hypothesis, we describe laboratory research practices, evidencing the operations of extraction and condensation of a significant for the construction of the diegetic framework. Bogart and Lecoq proposals are used, as well as the interface with other areas of knowledge, such as the Psychoanalysis of Jacques Lacan. We have come to the conclusion of the need for a material that functions as destabilizer of the arrangement, allowing the actor to be traversed by real experience, whose reactions will be situated, by the viewer's view, in the diegetic context.

Keywords

Poetics of the Body. Theater Pedagogy. Theater Drama. 


\section{Cena Corporal Performativa}

Indicar que o processo de construção de uma cena teatral é constituído por condensações e metonímias é atribuir-lhe um efeito de linguagem. Como o corpo pode se transformar na tela de onde se extrai um significante, que se junta a outro, para que um efeito de linguagem surja? Como se dá a escuta do corpo enquanto instância de um dizer? Estamos considerando este dizer sem articulá-lo necessariamente a um dito. Ou seja, levamos em conta que a poética aponta para um espaço de ausência de significação, através de formações instáveis que, em montagem, podem dar, à escuta, sentidos provisórios.

Certa vez, em um ensaio ${ }^{1}$, coloquei a seguinte regra para mim mesma: "reagir, com o corpo, às palavras". A produção corporal não seguiu a lógica da resposta às falas. Tratava-se dereação "ao ato de falar" (independente do que se falasse). $O$ que o corpo atualizava em suas pequenas explosões (como recortava as formas), eram formas impregnadas na memória que retornavam entre falas, preenchendo o "espaço vago" (como se a fala cedesse o bastão ao corpo nestes instantes de alternância). Com a aleatoriedade da forma produzida, o jogo entre desenho corporal e palavrase dá ao acaso; impera certa dose de abstração e, por outro lado, de sentido, quando se consegue capturar um.

Pode-se dizer que o que está em questão é um corpo imaginário, imagem unificada com a qual o sujeito se identifica como "eu"; para

1 Espetáculo criado no grupo de pesquisa Poéticas da Cena Contemporânea utlizado como um campo de investigação para o procedimento "Campo de Visão em Relação com o Outro": desdobramento do "Campo de Visão" em articulação com a "Ação Sobre o Outro", procedimento desenvolvido na Universidade Vila Velha a partir de proposições de Javier Daute. além de um corpo-linguagem (braço, perna, pescoço, ângulo, leve, solto, pesado, tenso), estilhaçado, compartimentado pelo verbo; e pode-se pensar neste verbo, também, não como linguagem, mas a lingua ${ }^{2}$, fazendo alusão aos "cacos" não inscritos na linguagem, pulsionais, não organizados, sons "sujos" de erotismo, que parasitam o corpo. A palavra fere o corpo (a palavra, dentro do jogo que situa um não-dito). O corpo, atualizado nas entre-linhas das falas, é aquele que suporta uma teia de relações com o verbo enquanto suporte de um não-dito.

Seria possível que o jogo da produção aleatória entre fala e corpo fosse realizado sem se alternar os tempos (da fala e do corpo)? Talvez se limitasse o corpo, pois o desenho corporal tende a ser absorvido no enquadramento da fala. Existe uma luta clássica entre a palavra e o corpo quando ambos determinam organizações do tempo-espaço que competem entre si. A fala também ocupa uma forma corporal (e o tempo do desenvolvimento desta para a sua enunciação). A palavra tende a absorver o desenho do corpo que seja estranho à necessidade de sua enunciação, limitando-o à própria incidência e ao enquadramento (diegético) que evoca.

Existe algo a se investigar, portanto, nesta "derrapagem" que o corpo é capaz de dar na palavra quando o desenho prima pela abstração e a regra de jogo é a alternância. Algo da forma corporal que se pode recortar ao acaso, afim de que a relação com a fala implique certa aleatoriedade, gerando uma amplitude para os passos-de-sentido. Quando, da relação entre palavra e corpo, captura-se o sentido da ação,

2 Conceito desenvolvido pelo psicanalista Jacques Lacan. Ver mais em: Soler, C. O "corpo falante". In: Fingermann, D. (org.) Caderno de Stylus, n.1. Rio de Janeiro, Internacional dos Fóruns do Campo Lacaniano, 2010. 
tem-se "um salto": "pula-se" para o contexto ficcional (cria-se enquadramento diegético). Mas, ainda assim, algo escapa deste enquadramento.

A poética corporal é fundada no manejo das relações espaço-temporais. Basta dizer para o ator "mais lento" que o corpo, enquanto tela, se refaz; e outros significantes são escutados; outra escrita de afetos é atualizada. Basta utilizar uma regulagem do tempo como, por exemplo, "câmera-lenta, explosão, desvio da direção do movimento seguido de pausa abrupta"3. A poética surge no intervalo entre a relação temporal e o que as formas evocam de escuta e enquadramento no olhar do sujeito que imagina ações provisórias. O espectador se coloca diante de algo que não estabeleceu ainda um sentido, mas tem uma regulagem qualquer que o conduz a pensar que "a cena fala". Um dizer sem o dito traz a expectativa da produção de uma diegese. Abstrações ritmadas possuem um dizer (ainda sem um sentido). Em que momento se dá o "passo-de-sentido"? Em que momento encontramos um "eu circunstanciado";um imaginário calcado pelas relações doeu com o mundo (figurativo); as fantasias que suportam a presença de um "eu" e de um "outro"?

Para chegar ao corpo unificado, figura de um eu circunstanciado, temos um "passo-de-sentido", um insight: "ver" relações intersubjetivas, identificar-se. Isto se dá com a extração de um significante, o seu deslocamento (metonímia) e a montagem (condensação) com outros, formando uma imagem. O olhar desenha a ação quando junta, evoca, desloca, produz a fantasia do "eu no mundo". Quando o Teatro Pós-dramático procura sustentar, não

3 Dinâmica experimentada em prática de pesquisa laboratorial. um universo diegético intacto, mas fragmentado e múltiplo,produz espaços abertos a múltiplas interpretações (e a perspectiva do sujeito incluir o seu desejo nesta escuta). Mas existem caminhos de escuta. Não do corpo-mapa, representativo de histórias, como em Decroux e a sua Mímica Corporal Dramática ${ }^{4}$. Estamos mais para Lecoq que, com seu "corpo poético", testemunha que o ponto de partida está na aleatoriedade das formas (mesmo quando paradoxalmente se pretende o corpo figurativo).

Quando Lecoq propõe um estímulo como "água" e o ator representa "a imagem da água" com o corpo, a forma deste corpo resta à imagem da água com a qual joga (obviamente não é possível que o corpo se transforme na imagem da água). É extraindo um significante da imagem da água (por exemplo, "fluido") que o ator se move (de forma fluida). Afim de figurar a água, produz outra coisa, da qual o espectador também extrai um significante. $O$ ator acaba por imprimir algo que serve para a construção de uma poética justamente na medida em não se escuta "água", mas outra coisa. $O$ espectador, ao escutar aquele "corpo-mapa", engendra uma outra cadeia de efeitos imaginários em sua montagem (fantasia onde está implicado um "eu circunstanciado").Cada um vê algo, depositando no "mapa-corpo", a sua relação com a linguagem e o mundo. Mas, o efeito poético só surge porque algo escapa a este sentido (imaginário), apontando um limite da linguagem. A metonímia e a condensação estão nestas montagens que deixam sempre "algo" escapar (neste lugar que é de "não inscrição"). E é quando aponta para este limite (ao apontar a falência de se dizer tudo) que a

4 Decroux promovia a narratividade, com relações e personagens circunstanciados, representados em um único corpo.

Arruda // Elemento Atrapalhador e Outros Princípios: a performatividade na poética dramático-realista 
arte "vence o jogo".

O que o corpo imprime do grafismo da imagem ("água"), no encontro com a própria materialidade, faz restar uma forma de onde o espectador extrai outro significante para engendrar a própria fantasia. Esta forma que restou seria uma grafia? Coreografia? Escritura cênica? Escrita corporal?Talvez a opacidade da letra, inscrita no papel-cena ou no corpo-página, "avulsa" porque não está em vocabulário pré-definido (letra sem destino), seja uma instância interessante a se trabalhar como princípio de composição cênica corporal. O que se escuta, desta letra e se extrai de significante para o jogo (da linguagem) acaba por compor o imaginário (no olhar do espectador). A letra sobra enquanto efeito poético na medida em que há relação entre ela e o significante extraído. Tal como diz José Miguel Wisnik (1999), a música acontece na relação entre o som e o ruído. A letra é o ruído da linguagem de onde é recortada, para a apreensão repentina de um sentido e, assim, o "passo", o "quase", o "meio" (sentido) - e a poética.

Há tantas marcas que, de um corpo, sobram ao jogo de apreensão de uma "imagem-água" (testemunho de que este se faz no acaso dos encontros). Mas há o recorte preciso, de algo que desliza no olhar do espectador, para que o passo-do-sentido aconteça e um contexto de ações se apresente (e depois se dilua). Há o momento de não-leitura, de espera, suspensão, de devir e insight. Lança-se mão de encontros fortuitos entre marcas do corpo-página e o processo metonímico da escuta de significantes, com o qual se desenha enquadramentos. Poder-se-ia dizer que a cena é performativa devido a este perpétuo exercício de escuta, extração e montagem.

\section{Corpus Subject Investigation}

No treinamento "Corpus Subject Investigation" o passo-de-sentido se dá a partir da abstração do movimento para, em seguida, extrairmos o significante que trará o sentido de uma ação de um "eu circunstanciado". Da mesma forma que o ator lecoquiano que ao incorporar a imagem da água acaba produzindo uma forma corporal que a excede, no "Corpus Subject Invastigation" partimos deformas plástico-corporais. As formas são construídas com o que Laban chama de "ações primárias". São verbos como "deslizar", "socar", "cortar", "pegar", "largar", "torcer", "furar”. As ações físicas resultantes guardam alta dose de abstração apesar de ser possível articularmos um fragmento de um eu circunstanciado.

A escuta do "eu circunstanciado" é engendrada após a inscrição do corpo em cena, em cadeia associativa constituída por livre-associação, ao acaso ou por encontro com a visualidade de materiais que o espectador dispõe (na sua própria relação com o mundo e repertório de vida ou pactuados com uma cultura). Estes materiais são evoca dos com as formas corporais. Por exemplo, uma atriz estava "brincando" com a ação primária "socar". A mão, indo e voltando diante da boca, associou a ação de escovar os dentes. Em um segundo momento, ela trouxe um batom e trocou pela ação de pintar (de forma grotesca) a boca,imprimindo uma boa dose de abstração implicada no enquadramento plástico-corporal que teve início com a ação primária "socar" (algo de abstrato que excede a representação da ação de passar batom). O corpo-tela, carregado de marcas, está impresso, enquanto se recorta o significante da ação que implica um eu (passando batom) engendrado no tecido social, 
tecido de uma fantasia que articula também outros significantes e imagens. $O$ instante da "compreensão da ação" é o mesmo instante da extração de um significante que se desloca para junto de outras imagens, construindo um contexto - produzido, por identificação (porque o espectador se coloca nestas imagens, lembrando de si ou algo do seu mundo, identificando a ação) e condensação. O estatuto do movimento cênico é alterado neste instante, passando à "ação física". Este instante envolve um prazer (de olhar).O próprio olhar interpretativo é evidenciado;espécie de "olho, logo existo"; pensamento esperando (entretido na busca), engendrando (em movimento, in loco, mexendo com os afetos).

\section{A Palavra em Cena}

A palavra se configura como uma linha de ação e, também, a textura da voz. O que se imprime, em forma de som, aparece como "ação vocal": mais um enquadramento para compor a fantasia de um "eu circunstanciado". Basta trocar a fala interna do ator ${ }^{5}$ para se imprimir outro desenho sonoro e outra ação para as mesmas palavras. A voz (em jogo com a fala interna) torna-se instrumento para oferecer ao espectador a perspectiva de "escutas" (no plural). Também com o seu desenho é possível criar arestas, desvios e justaposições, que se insinuam e se diluem; para que o espaço aberto suscite diferentes interpretações e preserve a ordem do indizível (sem, no entanto, se tornar hermético). Estamos falando aqui de "coreografia vocal", onde a abstração das linhas

5 Pensamento que ecoa em silencia, palavra endereçada ao outro que não se diz e que, no entanto, cria, articula, ação interna. também está presente.

O "jogo entre os enquadramentos" como operador do efeito de realidade é uma premissa. Cada jogo tem a sua "regra de proibição". No futebol, a mão na bola é proibida. Para produzir o efeito de realidade, a representação é proibida. Qualquer material presente (desenho corporal ou ação vocal), entra em relação com a palavra, gerando uma terceira coisa, relativamente instável, que se captura na hora.A visualidade da ação vem do jogo entre os diferentes materiais. A poética se dá por montagem, encontro, empilhamento e recorte (quando algo brilha no olhar em meio ao caos); relação entre caos e ordem.

Em montagem de "Navalha na Carne"6 no grupo "Poéticas da Cena Contemporânea", a regra de jogo foi utilizada como procedimento para a criação de enquadramentos sem que qualquer articulação estável entre ações físicas, diálogos e diegese fosse a anteriori produzida. O texto foi memorizado com a repetição da escrita (para provocar associações, substituições, grafias de afeto e fantasias que se mantivessem livres de qualquer vínculo com as imagens vocais), permitindo que a criação do enquadramento vocal se desse em cena a partir da relação com o outro. Com este procedimento foi possível que enquadramentos espaço-temporal (abstratos) articulassem a diegese a posteriori "sem querer" (por encontro e acaso) - ampliando o imaginário sobre o texto, a partir do que escutávamos da relação entre os atores, do jogo de cena e aproveitando-se da produção "aberta" que a Memorização Através da Escrita $^{7}$ constitui.

6 Montagem realizada no grupo Poéticas da Cena Contemporânea em função de uma investigação sobre a atuação realista.

7 Procedimento já problematizado em outros textos. Trata-se 
No enquadramento espaço-temporal (criado através de regras de jogo), surge o universo diegético. A "ação sobre o outro" e a palavra tensionam o enquadramento abstrato. Surge o "passo-do-sentido": instante em que as ações são constituídas, absorvendo a aleatoreidade das relações espaciais. E o que era apenas desenho gráfico ganha o sentido de ação. Esta ação é engendrada fora da intencionalidade do ator (cuja atenção está concentrada nas regras de jogo). Os elementos diegéticos advindos de uma fantasia (produzidos na Memorização Através da Escrita) são auxiliares e residuais. Assim, a tessitura da poética dá lugar ao não-sentido da estrutura espaço-temporal criada por uma regra de jogo aleatória, que passou a ter sentido na diegese quando por esta absorvida. Trata-se de sentido "não-todo"; uma borda entre a abstração e a figuração. Contempla-se os limites da forma dos enquadramentos e aponta-se para um lugar onde a forma da ficção não está presente. Esbarra-se no limite da forma da ficção, da ontologia dos seres e das suas ações ou pensamentos. Trabalhar esta borda é um princípio da construção do efeito de realidade quando se parte de relações puramente espaciais ${ }^{8}$. O enquadramento interno do ator (suas imagens, relações, fantasias) funciona como "absorvedor" (agente de absorção). O enquadramento externo (relações espaciais aleatórias) é absorvido no interno, ganhando sentido- na medida em que uma fantasia situa as imagens e dá vazão aos seus afetos. O enquadramento externo (aleatório) se trans-

de escrever o texto até a memorização.

8 Existem sistematizações de práticas contemporâneas que exploram relações espaço-temporais abstratas, como o "View-point" de Anne Bogart. Uma perspectiva de pesquisa que se abre é introduzir view points (estes sistematizados por Bogart ou outros a inventar) como regra de jogo no trabalho com a dramaturgia. forma (muda de forma), graças à pressão do enquadramento interno. O enquadramento interno é absorvedor e dilatador ao mesmo tempo. Organizando o ator internamente, permite que este se sustente no tempo e no espaço da cena por mais aleatórias que sejam as regras de jogo. Os dois enquadramentos dilatam.

A título de exemplo, as regras de jogo utilizadas em "Navalha na Carne" foram: a.) a cadeira nunca pode estar vazia; b.) sempre uma dupla e um sozinho (a dupla deve ser trocada de três em três frases); c.) cada um em uma ponta da sala (em relação de oposição); d.) em algum momento um tem que tocar a orelha do outro; e.) não podemos desencostar da cadeira; f.) cada um deve se contaminar pelo ritmo do outro; g.) cada um deve trabalhar o ritmo em oposição ao ritmo do outro; h.) andar em círculos e parar agachado (e depois repetir). Pode-se jogar com duas, três, quatro regras a um só tempo, aumentando as perspectivas de construção de ações físicas inusitadas quando as ações dramáticas encontram o enquadramento espaço-temporal.

"A cadeira nunca deve estar vazia" é uma regra aleatória. Não se sabe que relações ficcionais aparecerão a partir das trocas de lugar, de pegar, sentar, largar a cadeira, quando estes movimentos encontram as palavras lançadas no ar. Já tínhamos constituído uma perspectiva imaginária e alguma visualidade e afetos durante a Memorização Através da Escrita (repetimos o texto até o ponto de conseguir escrevê-lo sem olhar), mas o foco do jogo se mantém na regra que organiza os corpos em torno do objeto "cadeira", enquanto lidamos com a relação com o outro ator pela primeira vez experimentada. A coreografia com a cadeira contorna, desenha, fornece bordas e dinâmica às ações físicas, que surgem nas 
entrelinhas do texto dito com uma boa dose de abstração e pontos de entrelaçamento no enquadramento diegético. A cadeira acabou por se revelar um instrumento de: a.) agressão (Vado empurra Neusa e, com a cadeira, a pressiona contra a parede; b.) proteção (Neusa tira, com ímpeto, a cadeira da mão de Vado e a deposita com força no chão para em seguida sentar-se); c.) disputa (Vado vai atrás de Neusa e tira-lhe a cadeira das mãos; d.) figuração (Vado faz a cadeira de "mulheres" para provocar Neusa); e.) sedução (Neusa senta-se sensual).

A regra "sempre uma dupla sozinho" organiza um dispositivo onde deve prevalecer a alternância das posições espaciais: 2 e 1 em alternância. A cada três frases, deveríamos alterar a dupla. O jogo gerou vetores de movimento (gráfico, desenho, abstração) absorvidos na diegese. Em certo momento, o ator Fagner Soares estava junto a Mario Ferreira, Vado espancava Veludo. Ao falar três frases deveria se afastar. A regra de jogo gerou um vetor oposto à ação da personagem (circunstanciada pela diegese). Ao ceder a este vetor e, na medida em que este foi absorvido na diegese, criou-se uma contra-ação: ele une-se a Neusa, olha Veludo e, depois de algumas frases, vai novamente para cima. A partir de um grafismo aleatório e no momento em que a articulação com a diegese é produzida em improviso, a ação foi desenhada de maneira mais complexa. $O$ que era grafismo ganhou estatuto de ação. Os atores "preenchem" o espaço das entre-linhas dos desenhos gráficos produzidos por uma regra de jogo.

A diferença conceitual entre "ação dramática" e "ação física" torna-se instrumental. A ação dramática está inscrita no universo diegético, que implica a relação com o outro (o eu circunstanciado). Ela pode ser nomeada, constituindo-se como um "verbo-de-ação". $\mathrm{O}$ enquadramento espaço-temporal (a plasticidade cênica) pode apresentar-se como puro movimento, sem ter relação alguma com esta ação dramática. A ação física é a junção entre os dois: movimento mais ação dramática. A ação física concretiza-se com a absorção da plasticidade espaço-temporal na ação dramática. A ação física é a síntese da ação dramática com o enquadramento espaço-temporal. O jogo abre o espaço para a contingência dos encontros entre espaço-tempo cênico e ação dramática. Assim, descobre-se ações físicas que não se tinha visto, dilatando o imaginário (sentido) sobre a ficção.

\section{Corpo que Suporta a Fala}

Criamos falas internas para recuperar as ações físicas produzidas em jogo que tínhamos filmado.Estas servem de apoio; situando o foco, enquanto jogamos com o mesmo desenho corporal, devolvendo-lhe a vida (a incidência da fala interna dilata a ação física). Assim, recolocamos as ações físicas em cena, definindo a partitura física (fixa). Repetimos as ações com a fala, que escapava de início. A Memorização Através da Escrita não dá conta da embocadura do texto, da fluência da fala e sua dinâmica. É realizada para outros fins, como: evitar a formatação da oralidade do "decorado" antes de se ir para a cena, constituição das ações vocais junto às intempéries das ações, gerar material residual, acordar a memória corporal, produzir substituições, transformar os sentidos, criar fala interna.É necessário, para que a dinâmica da cena flua, a repetição da oralidade junto às ações físicas já 
constituídas no improviso.

Existe a dimensão superficial desta "fricção". A superfície da cena implica uma relação plástica entre os atores: a sobreposição ou alternância das vozes, tempos de espera, os contatos, as rupturas, as alternâncias de movimento. É como se o espaço tridimensional (que se abre a partir das falas e visualização internas) sumisse. A superfície da cena, friccionada, esquenta tanto, que não dá tempo para o ator concentrar o foco em materiais de abertura deste "interno" - que se configuraria como outro eixo, transversal ao da cena. A superfície lateja. É possível que o ator a rompa, dedicando-se a "resolver o problema" do foco no material interno. Isto pode se dar paralelamente às ações físicas e vocais ou rompendo-as e abrindo tempos de silêncio (pausas, desaceleração, defasagem). Mas o que normalmente acontece é: estes materiais internos são elaborados "no calor do momento" em nome próprio. Ou seja, não se trata de material diegético (pensamento do personagem, uma das camadas residuais neste momento) e sim do ator pensando "coisas" em nome próprio enquanto as ações físicas "fervem". Este "estado de explosão" acontece com a repetição das "fricções" (das falas junto às ações físicas). É como acender uma fogueira com dois tocos de madeira. É preciso raspar várias vezes até conseguir a faísca que vai queimar a madeira e gerar a chama.

O princípio de construção de uma superfície explosiva através da fricção não desautoriza ou desvaloriza procedimentos de constituição de falas internas e visualização, que se mantem residuais. Este princípio revela-se como um vetor em oposição à fricção, causando rupturas na tessitura da cena e justaposições - abrindo um eixo tridimensional, gerando pro- fundidade e constituindo enigma. Trata-se, novamente, de jogo em um dispositivo complexo, com vários vetores que se relacionam de forma não harmônica (os procedimentos são heterogêneos entre si).

\section{Cotidianidade e Tipificação}

Na montagem de "Navalha na Carne", a presença da cotidianidade foi utilizada como uma regra de jogo: abrir a porta como sempre faço e sentar no sofá. A cotidianidade imediatamente traz um eu-circunstanciado. $O$ jogo fica mais complexo ao utilizarmos a regra de produzir monólogo interior durante a cena ou "toda vez que houver silêncio ir até a janela". Estas regras trazem, além da cotidianidade, a visualidade do pensamento - revelada como espaço enigmático onde se passam imagens vetadas ao público.

Provocamos a incidência de materiais residuais antes de entrar em cena,descrevendo programas supostamente vivenciados com o uso de substituições (Hagen, 2007): pessoas com as quais tive qualquer tipo de relação profissional e pelas quais eu sentia uma espécie de repulsa (no que diz respeito à estranheza dos corpos, o dente manchado, suor, cabelo desgranhado). Imaginei programas. As palavras no papel servem como um trilho de afetos repulsivos. Para entrar em cena, mais uma substituição: a escuta foi situada na fala interna "Eu tenho que mudar de vida, eu não aguento mais". É possível uma articulação com a fantasia sobre a personagem (que supostamente estava cansada). O ponto de partida não foi a representação do cansaço, no entanto, mas a criação de um suporte interno com a mesma lógica. 
A "cotidianidade" entra como um arranjo não circunscrito ao ato de representação da personagem, mas à construção de uma poética específica do corpo, que se vale de um conjunto de princípios: a substituição repentina da fala interna pela externa (para produzir a ilusão de que a palavra é formulada na hora), a divisão de foco, as expansões de tempo e sobreposição ou atrito de vozes, a enunciação oscilante, as variações de volume e de velocidade, a imprecisão e indeterminação da forma corporal. Em um segundo momento, precisei também da tipificação "puta velha", o que conquistam os com o significante "bandida": um "quem" em jogo,que circunscreveu, recortou, dilatou e absorveu os desenhos corporais exercitados em treinamento com a prática pré-expressiva Campo de Visão9. O "quem" é outro enquadramento (cotidianidade e tipificação se tencionam). A forma corporal (tipificada) que articulamos ao "corpo de Neusa Sueli" constitui-se também como um trilho,como se a máscara corporal fosse "Neusa". Trata-se do que Stanislavski chama "caracterização". Mas não partimos da representação da prostituta, e sim da absorção de registros produzidos na prática pré-expressiva "Campo de Visão" (os registros foram atualizados no jogo com o quem "bandida").

Desde início (em menor grau) a tipificação havia se infiltrado junto à cotidianidade, quando trabalhamos resíduos com a escrita e substituições e,ao entrar em cena com o foco na fala interna "preciso mudar de vida", o andar se modificou. Os repertórios corporais, quando encontram a visualidade ficcional, "vazam"

9 O Campo de Visão é um procedimento para a abertura de repertório plástico corporal para a criação cênica desenvolvido na UNICAMP e sistematizado por Marcelo Lazzaratto. Ver mais em Lazzaratto, M. Campo de Visão e Linguagem Cênica. São Paulo: Ed. Associação de Arte, 2011. para a cena. Isto na medida em que funcionam como auxiliares para ações produzidas no próprio contexto de jogo. Assim, instauramos, a cada ensaio, a dinâmica do "Campo de Visão"antes de entrarmos em jogo com o texto e após a Memorização Através da Escrita. O Campo de Visão se vale dos enquadramentos internos constituídos durante a memorização, que dizem respeito à produção de fantasia sobre as personagens, suas ações e seus pensamentos. Misturandoa "Ação Sobre o Outro"10 ao "Campo de Visão" as ações físicas eram visivelmente atravessadas pelo imaginário das relações Vado-Neusa, Vado-Veludo, Veludo-Neusa. Ainda sem o filtro das falas, as ações tendiam para uma exacerbação plástico-corporal e o o excesso, a deformação; um visível "laboratório de formas". Estas formas são filtradas (ou diluídas) na teia-filtro-fala-ação interna, quando se coloca em jogo a própria ideia de realismo. São recuperados através de desvios, de traições, de desafios à forma realista. As formas adquiridas em treinamento extra-cotidiano resultam armazenadas, soltas, prontas a serem acomodadas no jogo com o texto, apesar da ênfase não estar na plástica corporal, mas na plástica das relações. Força-se a movimentação para que esta se acomode no fluxo das relações, nos "entre-dois". Sem contrapor emoção e razão, ou forma e realismo, pois o realismo tema própria forma (os corpos precisam estar imbuídos da cotidianidade, mesmo em jogo coma tipificação e o estranhamento que advém da relação entre diegese e cena). O pensamento do personagem precisa aparecer como uma tessitura, cama-

10 Uma outra modalidade de treinamento, desenvolvida na Universidade Vila Velha a partir de proposições de Javier Dalte, onde a ênfase recai para ações para provocar o outro, retirando-lhe de sua "zona de conforto", desafiando os limites da relação entre-dois. 
da, superfície da cena. Ao invés de dicotomias como "emoção versus razão" e "emoção versus forma", ou "realismo versus formalismo", propomos: "enquadramento na relação com o outro" versus "enquadramento na plasticidade corporal". Trata-se de um jogo com enquadramentos diferentes em oposição, o que cria tensão e resolução em cena. $O$ enquadramento (organização) plástico corporal "joga" com o enquadramento pela relação com o outro, que também tem a sua forma, os seus limites e suas perspectivas de dilatação.

\section{Absorção de Novas Diegeses}

"Navalha na Carne" tem início com Vado aguardando a prostituta Neusa Sueli para saber o que foi feito do "tutu" que ela deveria ter deixado (como todo dia). Sem saber que foi Veludo (o arrumador dos quartos do cortiço) que pegou o dinheiro, Neusa não entende do que o homem fala e leva uma surra. O caso é solucionado quando Veludo, sob tortura, confessa. Mas depois que sai, o conflito se adensa entre Neusa e Vado, até a agressão psicológica e coação (com o uso de uma navalha).

$\mathrm{Na}$ leitura do texto, somos levados a pensar que "a bronca" de Sueli é por ciúmes. Durante a presença de Veludo acontecem inversões: Neusa e Vado se tornam cúmplices e, depois, Vado torna-se cúmplice de Veludo, deixando Neusa incomodada. A partir do jogo com regras, lendo, nas entre-linhas, o espaço onde se situa um não-dito, o trabalho de dilatação imaginária evocou o que Ryngaert chama de "implícito": o interesse de Vado em cafetinar garotos, já que a "puta velha" não está dando dinheiro como antes (em momento algum indicado). Este enquadramento apareceu quando os atores foram receptores da visualidade das ações impregnadas na vivência do jogo (pois jogamos, não com a representação, mas com as regras), sem a tentativa de representação do que sabíamos (dito no texto), mas produzindo o que não tínhamos visto. O insight levou à reelaboração do enquadramento e criou ações internas, que se desdobraram, sustentando a erupção do afeto a partir de certa lógica, trazendo a visualidade deste (outro) mundo: o não-dito do personagem, o seu pensamento escondido (aproximando-nos da atuação naturalista e dramática).

O pensamento do personagem foi construído por "dilatação imaginária", quando as frases reverberavam em escuta fora de cena: "Você pensa que eu não percebi a sua jogada com o Veludo?" (Neusa Sueli) e "O que você gosta mais, de maconha ou de moleque?" (Vado). A palavra "moleque" ecoou, quando podíamos rememorar a vivência do jogo, tendo a visualidade das ações físicas diante dos olhos (exercitando a escuta da cena e não do texto literário).A partir da vivência (rememorada) que da cena, no encontro com o texto, o insight. Este poderia ter vindo em qualquer momento: no meio da rua ou no ponto de ônibus, acordando, conversando, mas veio durante a Memorização Através da Escrita11. O "moleque" (não "jovem" ou "peguete") trouxe uma cadeia de significantes: menino, criança, menor, Querô ${ }^{12}$. Antes da articulação de "moleque", as frases não tinham valor para a atriz ("Eu tenho é moral"; "Só sei que você me embrulhou o estômago", "Só não sou é de bacanal"). Veludo paga crianças para ser tocado; Vado se interessa em

11 Contextualizado anteriormente.

12 Personagem-título da peça "Querô", de autoria de Plinio Marcos. Filho de uma prostituta que tomou querosene quando ele era bebê, Querô é assassinado por policiais. 
cafetiná-los: foi esta a fantasia que conseguiu enlaçar pulsionalmente a atriz, afim de deixar-se levar pela "ação sobre o outro" e borrar os enquadramentos advindos das regras de jogo, produzindo o "efeito de realidade".

A ideia de que Vado pensa em cafetinar garotos é um enquadramento capaz de absorver a aleatoriedade das partituras físicas criadas com regras de jogo, dilatando-o em função de um afeto gerado a partir desta lógica e olhar. $O$ afeto provoca ação sobre o outro, "sujando", bagunçando as relações espaciais organizadas com as regras de jogo. O ódio é sustentado com a fala interna: "Ele pensa em cafetinar os meninos!!!". A energia é canalizada para a "ação sobe o outro", dilatando o enquadramento cênico plástico-corporal advindo dos jogos;transbordando-o, excedendo-o, deformando-os, desafiando os limites de sua forma. Atua-se "nas bordas" entre caos e ordem, na borda dos enquadramentos, que se tornam instáveis.

\section{O Elemento Atrapalhador}

"Vamos brincar de destruir esta partitura?" A regra de jogo passou a ser: "Não executar a partitura". Nós nos colocávamos em relação a sua visualidade e fazíamos outra coisa. A partitura passou à camada residual. Isto fez parte de um momento, até percebermos a força do elemento "atrapalhador": a exacerbação da violência. $O$ foco passou a se concentrar em pontos de agressão e defesa, reações abruptas, o detalhe do corpo do parceiro, a sensação. Trata-se de um desestabilizador de todo o arranjo. Graças a um pacto firmado desde o início, o espetador situa a produção cênica no contexto diegético. De acordo com Kusnet (1975), a "primeira instalação" (contexto do ator) evoca a "segunda instalação" (contexto do personagem). A reação é tomada como produção da personagem.

Todo ato criativo implica um salto no vazio. O salto tem de ocorrer no momento certo e, no entanto, o momento para o salto nunca é predeterminado. No meio do salto, não há garantias. $\mathrm{O}$ salto pode muitas vezes provocar um enorme desconforto. O desconforto é um parceiro do ato criativo - um colaborador-chave. Se seu trabalho não o deixa suficientemente desconfortável, é muito provável que ninguém venha a ser tocado por ele" (Bogart, 2011, p. 115).

O ator, na atuação realista, precisa lidar com certa instabilidade ou o efeito de realidade não acontece. Novamente, o princípio: o ator atua em nome próprio, o que o permite criar um "efeito de personagem". Esta é uma possível maneira de conceituar "o personagem": enquanto enquadramento. Não mais o corpo-máscara (que é a plasticidade corporal), mas a visualidade que se evoca na "ação sobre o outro", na relação com o outro. O personagem só se configura nesta relação. Contamos com o enquadramento da "visualidade da relação" e de como esta afeta o ator.

O princípio da apropriação do próprio contexto é avassalador. É ali que está a verdade do ator, mas, às vezes, é difícil os atores compreenderem, porque vai contra a sua necessidade de representar um personagem e se sentir "outro". O conceito de "corpo-máscara"é interessante, pois traz a alusão à alteridade. No entanto, é produto (resultante) de um arranjo completo (e ao mesmo tempo um dos materiais). É preciso abandoná-lo às vezes e se tornar vulnerável a outros fatores. É preciso pô-lo em jogo, para um ato de improvisação sempre novo. 
O mesmo acontece com a partitura física já formatada: ela entra em jogo; é um material (e não um "encapamento único"); assim, não deve estar presente sem fissuras. O mesmo com um "personagem": é um "quem" em jogo, é um dos materiais; como figuração de outra subjetividade, é um dos materiais apenas. Sempre vai estar lá o ator, em nome próprio, jogando e, também, com o seu desajeito, com as sensações novas dentro do seu próprio contexto.

De início, ela parecia desajeitada e sem sofisticação, mas logo ficou visível que ela era, de fato, uma cantora de verdade. O ato de cantar, a intensidade do som que emanava do corpo dela aumentava sua vulnerabilidade. Sua própria timidez a desconcertava e ela parecia ligeiramente envergonhada. Se a pessoa não for "tocada" pelo ímpeto daquilo que é expresso através dela, então, como observou Gertrude Stein a respeito de Oakland, Califórnia, 'não tem lá'. Talvez Judy Garland levantasse os braços no que se tornou sua imagem emblemática por causa de sua sensação de vergonha. Desse momento em diante, cantores e drag queens passaram a imitar o movimento exato dos braços dela em absoluta adoração (Bogart, 2011, p. 116)

Bogart (2011, p. 117) fala sobre "atravessamento" e "vulnerabilidade". A "vergonha" é um "elemento atrapalhador". Algo soa como o princípio-base: "Esteja preparado para se sentir desconfortável". Ela contextualiza a origem da palavra "vergonha", que está ligada à ideia de "barra":

A palavra embarassment, desconforto, surgiu na língua inglesa em 1672 e deriva do francês embarasser, que quer dizer enredar, obstruir ou incomodar; atrapalhar; impedir, tornar difícil ou intrincado; complicar. Em português, barra, é uma barra ou uma obstrução" (ibi- dem). O "elemento atrapalhador" é algo fora do controle, que não dominamos - enos deixa vulnerável. Seja a violência em "Navalha na Carne" ou a timidez típica dos iniciantes, este elemento faz parte da estrutura do trabalho criativo; "puxa" o foco de atenção, tomando-o por completo, prejudicando a divisão (do foco, instância teorizada por Spolin) com os outros elementos. Isto causa tensão, exige esforço, que traz energia e dilatação - desde que não se saia de cena, não se interrompa o fluxo do estar em cena.

Quando você luta contra algo que está fora do seu alcance, se vê envolvido naquilo que ainda não domina. $O$ desconforto é um mestre. O bom ator corre o risco de se sentir desconfortável o tempo todo. Não há nada mais emocionante do que ensaiar com um ator que está disposto a pisar em território desconfortável. A insegurança mantém as linhas tensas. Se você tenta evitar sentir-se desconfortável com o que faz, não vai acontecer nada, porque o território permanece seguro e não é exposto. O desconforto geral brilho, realça a personalidade (..) A sensação de desconforto é um bom sinal porque significa que você está entrando em contato com o momento de maneira plena, aberto aos novos sentimentos que esse momento vai gerar (Bogart, 2011, p. 118).

A "função do não saber" se revela; a necessidade de deixar um espaço para a impressão, em cena, do próprio contexto de não saber: isto é um ato poético.

Depois de atuar em uma peça durante um ano inteiro, Vanessa Redgrave se deu conta de que havia partes do espetáculo que ela simplesmente não sabia como fazer; portanto, resolveu deixar esse não saber aparecer enquanto ela o descobria (...) Aconteceu que esses momentos se revelaram absolutamente fascinantes. Imagino que a força de ela não saber atravessou a 
noite. Acredito que ela se sentiu mais exposta, mais vulnerável e, provavelmente, mais presente e alerta (Bogart, 2011, p. 119).

Também existe o princípio da partiturização (de "saber o que fazer", pois a partitura está programada). Também ser preciso na execução, como um jogador de basquete visualiza a trajetória da bola um instante antes de jogá-la, no ângulo e com força necessária para encachapa-la na cesta (porque sabe o que fazer). A "política do $E^{213}$ nos propõe lidar com princípios opostos sendo que um não anula o outro (eles se tencionam e podemos alterná-los ou misturá-los).

\section{Conclusão}

A nossa resposta para o problema da performatividade e dos efeitos de realidade em uma poética dramático-realista é: partir da abstração, absorvendo a aleatoriedade do enquadramento abstrato constituído por um jogo de regras na ação sobre o outro; com o auxílio de materiais residuais e a divisão de foco com a fala interna (enquanto resíduo ou em escuta) e uma espécie de hibridismo entre a cotidianidade e a tipificação - quando se mantém o treinamento extra-cotidiano. O "elemento atrapalhador" tende a destruir o arranjo, "desmanchar o castelinho", a provocar o caos. Ele arrasta tudo para outra direção; bagunça o que estava ordenado e causa uma reação imediata, viva. Ele reestrutura o jogo. O que era intacto, se fragmenta ou se torna resíduo.

13 Princípio de trabalho problematizado em outras publicações, a "política do E" propõe que os materiais heterogeneos entre si entrem no mesmo arranjo como vetores em oposição, de maneira que a dicotomia não anule a utilização de um dos materiais (troca-se a política do "ou" pela política do "e").

\section{Referências}

BOGART, A. A Preparação do Diretor. São Paulo: Ed. Martins Fontes, 2011.

HAGEN, U. Técnica para o Ator: A Arte da Interpretação Ética. São Paulo: Ed. Martins Fones, 2007.

KUSNET, Eugênio. O ator e o método. Belo Horizonte: Mincinacen.1975.

LAZZARATTO, M. Campo de Visão e Linguagem Cênica. São Paulo: Ed. Associação de Arte, 2011.

SOLER, C. O "corpo falante". In: FINGERMANN, D. (org.) Caderno de Stylus, n.1. Rio de Janeiro, Internacional dos Fóruns do Campo Lacaniano, 2010.

Recebido: $26 / 07 / 2017$

Aprovado: 21/11/2017 